\title{
Space syntax as a socio-economic approach: a review of potentials in the polish context
}

\begin{abstract}
The article presents selected issues within the field of space syntax, its theoretical assumptions, and application possibilities, taking into account, especially, works in the field of social and economic geography, and spatial management. The article attempts to present Polish works in the field of space syntax as related to the wider spectrum of its global applications. In Poland, the theory and research tools of space syntax are rarely used. It appears that there are two factors that influence the current marginalisation of space syntax. The first one is the relative complexity of the research procedure, which requires knowledge of specialist computer software. The second arises directly from the fact that, in reality, only occasional use of space syntax tools has been attempted within the Polish arena. This determines the actual lack of a native space syntax community that would support subsequent researchers who are ready to conduct such studies.
\end{abstract}

Keywords

Space syntax $\cdot$ social and economic geography $\cdot$ spatial management $\cdot$ Poland

Introduction. From social and economic geography to space syntax

Studies on the spatial aspects of human functioning have been developed on the foundation of numerous disciplines, sub-disciplines, and academic environments. These include behavioural geography (Cox \& Golledge 1981), socio-biology (Wilson 1975), architectural psychology (Zeisel 1975), evolutionary psychology (Neuberg, Kenrick \& Schaller 2010), anthropology (Graves 2004), and proxemics (Hall 1976; Hendrykowski 2015), but also social and economic geography and spatial management, recognised in Poland in 2018 as a single academic discipline (Ministry of Science and Higher Education 2019). This discipline's most essential fields include land-use planning and spatial organisation at various scales, and in accordance with the current needs of societies, actions aimed at improving living conditions, including mobility and accessibility, and the identification and analysis of factors encouraging specific types of behaviour in space as well as their social and economic consequences: that is, everything that emerges from the overlap between the environment and the society that uses it (but also constructs it).

Actions such as locating investments, or changing the design of the built environment or the society's organisation of its production are merely a means to the above-mentioned end. Therefore, the fields of social and economic geography, and spatial management, as perceived in the broad sense, use on a daily basis both that which is immaterial (ideas) and material (objects) to shape that which is social. In terms of the practical actions associated with the spatial organisation of human activities, this is nothing new. However, aspirations to break the anthropocentric paradigm, which appear in modern humanistic thought, provide new perspectives on the reality surrounding us and created by us. They can also contribute to new studies and interpretations of observed phenomena and socio-economic

\author{
Mariusz Lamprecht \\ Institute of Built Environment and Spatial Policy, \\ Faculty of Geographical Sciences, \\ University of Lodz, Lodz, Poland \\ e-mail: mariusz.lamprechł@geo.uni.lodz.pl \\ Received: 29 January 2020 \\ Accepted: 4 October 2021
}

processes. These include the so-called 'turn to things' (ed. Appadurai 1986; Schleretch 1991; Barański 2007; Olsen 2013), and ascribing causative power to objects, for example, in the actor-network theory (Latour 2010; Abriszewski 2008). The 'spatial turn', conceived by Lefebvre (1991), wherein space is not the 'container' of events generated by people but a fully-fledged actor, actively influencing the societies functioning within, should also be mentioned here. Such an approach leads to socio-spatial dialectics, wherein the spatial shapes the social as much as the social shapes the spatial (Soja 2009). Since space in not an objective being, it is conceived (designed), perceived (observed), and lived (experienced) (Lefebvre 1991). In this approach to social and economic geography and spatial management, and in reference to the actor-network theory, non-human agents are used to shape that which is human.

One of the research currents dealing with spatial agency is space syntax. From the perspective of space syntax, the configuration of space is perceived, analysed, and assessed as a framework that influences the functioning of the societies that use it. As Hillier (1996 pp. 280-281) noted, 'the human agency is in the physical shaping, locating and orientation of built forms. The laws [of space] are in the emergent spatial effects consequent on those physical decisions. Built forms, we may say, are shaped, located and oriented by human agency, but in the light of laws which control their effects'. The purpose of this article is to introduce the theoretical foundations of the current achievements and applications of space syntax in social and economic geography and spatial management. The purpose is justified in light of the major achievements of space syntax in the global arena, and its minor significance in Poland where this theory and its research techniques are relatively obscure and rarely used despite their major analytical and explanatory potential. 
The analysis of current space syntax works was based on sets of texts prepared for space syntax symposia as well as texts indexed by Google Scholar, Mendeley, and Google search engines. And since Polish authors' contribution to the development of space syntax has been so minor, the process of compiling these works was laborious and required significant investigative skills. In this case, publications in paper form were also analysed, since it was the only form available.

This text provides no descriptions of the techniques or tools applied in the field of space syntax. Those can be found in large quantities in the subject literature (e.g. Hillier \& Hanson 1984; Turner 2001; Turner, Penn \& Hillier 2005; Al-Sayed et al. 2014; Van Nes \& Yamu 2018).

\section{The foundations of the space syntax theory}

Knowledge about human behaviour in space $^{1}$ is perceived as being key information in making it possible to understand and predict the way modern societies function. The behaviour of people in specific spatial contexts is especially important for the proper spatial organisation of societies. What matters is how far people are willing to go to get to a destination of a given rank, which route they choose, when and how they decide to choose a given form of transport, which locations are especially attractive, which aspects hinder and which create conditions favourable for walking, whether there are spaces that encourage a specific type of behaviour, etc.

The search for the foundations of interactions between man and the environment that is used and produced by him interested for the first time, the staff at the Bartlett School of Architecture, University College London. The Space Syntax Laboratory was founded in 1972, on the initiative of Professor Bill Hillier. At the root of its studies lay the conviction that the key factor influencing the fulfilment of the social functions performed by a built environment is the configuration of the space within buildings and between them. The first highly significant publications in this field included The Social Logic of Space (Hillier \& Hanson 1984) and Space is the Machine: A Configurational Theory of Architecture (Hillier 1996), although some works on morphic language, such as Space Syntax (Hillier et al. 1976) and Space Syntax. A Different Urban Perspective (Hillier et al. 1983) were published much earlier.

Space, as defined by space syntax, is a relationship; that is, a specific method of connectedness, relatedness. Such relationships, produced and shaped by material objects (e.g. buildings), are experienced by people, the users of given spaces. That is why space is a part of movement, interactions with other people, and even the process of observation (Hillier \& Hanson 1984). A basic feature of space in this sense is configuration, that is, the set of relationships existing within a given structure (e.g. relationships between streets in a city or rooms in a building) (Hillier, Hanson \& Graham 1987; Hillier 2007). Each structure (e.g. a city) is characterised by its own configuration. And since its individual elements are interdependent, each modification, for example, carving a new street into a city's outskirts or building it as a result of a new land development, leads to a change in the relationship between all the elements of the structure.

From the perspective of space syntax, it is crucial to assume that the configuration of the spaces that make up a given spatial layout (e.g. of a hospital, airport, or city) influences man's spatial

'There is a difference between spatial behaviour and behaviour in space. When recognising spatial behaviour, the models and assumptions describing the behaviour, regardless of the spatial structure wherein the behaviour occurs, are looked for. In other words, researchers seek the rules of selection, movement, and interaction, which are not dependent on the spatial system wherein the behaviour occurs. Behaviour in space describes behaviour related to existing spatial structures. Therefore, the way a structure is built explains behaviour (Cox \& Golledge 1986). This article deals with this last aspect. and social activities. Therefore, in this approach, two elements are vital: the structure (configuration) of space wherein the social processes of interest occur, and the way in which man perceives and interprets the surrounding space. As a result, specific patterns of behaviour emerge in space. Configurational analysis helps in searching for the relations between the spatial system and the social processes occurring within it. Thus, the social functions of the man-made environment are of greatest interest (Hillier \& Hanson 1984; Peponis \& Wineman 2003).

Space syntax encompasses both a theory (space syntax theory) and a collection of analytical tools (space syntax analysis), which make up the mosaic of mathematical ideas used to study spatial layouts and spatial models of human activity (UCL Space syntax 2020; Hillier 2012). The attractiveness of space syntax lies in the fact that the approach offers a new calculation language, based, among others, on graph theory and able to describe the spatial configuration of the man-made environment. Yet, it should be remembered that man, human knowledge, and spatial skills, along with the various consequences caused by a specific sociospatial environment, are fundamental to building a model of urban space, and interpreting it. This makes it easier to perceive space as an active factor whose agency depends on the way in which space is interpreted (on the level of an individual, but, as a result, also of society). Therefore, space is not perceived as an objective fact but a social one (since that is how it becomes an actor, or 'the influencing one').

The existence of relationships between the mathematical description of space and the presence of people within it has been proven in the field of space syntax. It has also been suggested that it is the topology and not the geometry of street grids - the relations between streets and not their geometric features, such as length or curvature - that plays a major role in explaining people's collective types of behaviour (Ma et al. 2019). The research results also indicate that the spatial models of human activities are far from coincidental. This proves the existence of certain types of spatial order (hierarchies) in the societies that make use of specific territories. However, it should be emphasised that space syntax cannot predict the behaviour of individuals, but is used instead to analyse and assess the influence of spatial configuration on collective types of behaviour. It is impossible, therefore, to predict which path will be chosen by an individual, but a path used more often than other paths can be identified.

It should be stressed that space syntax is a still developing field of knowledge. New, alternative models and analyses of urban space, based on street segments, natural streets, and new axial lines, are continuously being developed (Turner 2005; Jiang, Zhao \& Yin 2008). The software that supports the analytical process (e.g. Axwoman 2015; DepthmapX 2020; PM Place Syntax Tool 2020 ) is also in constant development. Further development of space syntax could advance in four directions: as a theory on the built environment constructed as an object, as a theory on urban networks and movement economies, and as a theory on urban networks and economic development (Van Nes \& Yamu 2020).

The weaknesses of space syntax include both purely technical matters, such as those related to the way in which city models are created, which enables the researcher to have interpretative freedom (Kostakos 2010; Ratti 2004); and those regarding methodological and theoretical assumptions. The latter include taking into account only two dimensions of a threedimensional urban reality (i.e. city plan), and ascribing too big a role to the configuration of space in the functioning of societies. Issues such as the edge effect, changeability of results depending on the spatial scale of research, and difficulties in capturing spatiotemporal changeability, are also mentioned (Montello 2007; Pafka, Dovey \& Aschwanden 2018; see also the discussion by Ratti 2004, 2005; Hillier \& Penn 2004). The theory has been faulted for stripping space 
of its semantic meanings and reducing social actors to mobile automatons trapped between material obstacles (Netto 2016). Yet, it should be emphasised that space syntax seeks the social logic of space by focusing on mass observations and statistical generalisations. The identification of specific spatial patterns does not take away people's rights to individual, spontaneous, and unpredictable decisions.

\section{Space syntax research in the context of international publications}

Research that uses the theories and methodology of space syntax is currently widely used by Professor Hillier's team, his students, and a variety of researchers from all over the world. The achievements of the space syntax current are observable in the form of at least several thousand research papers. Space syntax symposia, organised every two years (since 1997), are the perfect opportunity to exchange experiences and knowledge, both theoretical and practical. This current of studies is oriented towards the development of methodology (in light of the increasingly common availability of data), new research tools (mostly in order to automate certain actions using computer software), and fulfilling cognitive purposes. The achievements of space syntax to date have been a major contribution to practical activity, especially in the scope of the spatial organisation of human activity in the broad sense. It is impossible to describe, even briefly, all the achievements of space syntax, therefore, only selected research areas have been presented, omitting, for instance, works whose purpose is the development of the theory itself or analytical tools.

It is not easy to classify works within the field of space syntax due to its wide range of applications. According to Karimi (2018), space syntax can be seen as 'an umbrella for socio-spatial studies' that are based on the evidence it collects as well as its research tools and techniques. Yet, these words suggest that, on the one hand, there is a set of works that shape the foundations of space syntax, and, on the other, the current serves as an inspiration to other research currents. In reference to the theory of natural movement (Hillier et al. 1993), the first set includes works dedicated to the configuration of the urban system and the attractors, that is, destinations, or, in broader terms, all the ways in which land is used in urban space as well as pedestrian movements. These constitute the foundations of space syntax, according to which 'society must be described in terms of its intrinsic spatiality; space must be described in terms of its intrinsic sociality' in opposition to the numerous ways in which social theorists have conceptualised society, resulting in 'desocialising space and despatialising society' (Hillier \& Hanson 1984, p. 26). From this trunk emerges a crown that grows with time and becomes ever more complex. Its branches represent disciplines, sub-disciplines, and research currents that draw on the works of space syntax, both its theoretical bases and empirical evidence.

In this division into the fundamental types of space syntax works (not official, but widely agreed upon due to the inseparability of these notions) dedicated to urban morphology must also be mentioned. Their authors have mostly focused on the configurational properties of urban layouts. This enables them to identify their internal structure, for example, the hierarchy of a street network (Tomko, Winter \& Claramunt 2008), especially the features of internal structure such as isotropic gridded cities like Lubbock (Haq \& Berhie 2017), or the imperceptible features of the morphological logic of organic structures. Yet, apparently, behind the organic and seemingly unplanned spatial patterns may lie the hidden intentions of their creators, taking into account defence, social, or climactic requirements (Ramzy 2016). The structures of organic cities differ configurationally from new cities established in accordance with comprehensive city plans and the 'tree-like' hierarchical street networks or the 'neighbourhood units' based on modern concepts (Omer \& Goldblatt 2016).

Analyses, on a major scale, are conducted on metropolitan areas, small settlement forms, and even individual urban layouts or buildings, whether existing, present in vestigial form, or merely in the form of plans. Frequently, they reveal the unexpected structural features of spatial systems, providing insight into the spatial organisation of the societies that use them (Foster 1989; Van Nes 2009; Serra \& Pinho 2013; Aydoğan \& Şalgamcioğlu 2017; Coutinho, Santos \& Fernandes 2017).

The form of the urban structures is naturally connected to the spatial organisation of the societies that use them. Numerous analyses indicate that the configurational parameters of space are reflected in both the functioning of economic entities and in the patterns of their distribution. For instance, the analysis of street centrality indices and their correlations with various types of economic activities in Barcelona, Spain, showed that the secondary activities, which are strictly linked with the movement of economy, seek the most central locations. On the other hand, primary activities have more freedom when choosing locations, since they have the power to attract people. This, in turn, suggests that the main urban arteries, which have high centrality values, should be perceived by planners as being cores rather than the borders of neighbouring units (Porta et al. 2012). Similarly, an analysis of the spatial organisation of economic activities in old Antwerp showed a statistically significant relationship between selected types of activity and the level of centrality of the streets they were located on (Froy 2016). Similar regularities were observed in analyses dedicated to the excavated city of Pompeii (Van Nes 2009).

In turn, Chiaradia et al. (2009) assessed the relationship between the configuration of streets and the value of residential properties. Their studies showed that the level of spatial integration has a major, and also positive influence on the higher tax ranges. The analyses conducted by Kim and Sohn (2002) confirmed the relationship between the measures of spatial configuration and the intensity of land use (within the scope of office buildings). On the other hand, Enström and Netzell (2008) proved that the level of integration of urban space is connected to office rent rates, while Brown (1999) noticed that the configuration of a shopping centre can be partially responsible for its success or failure.

Last but not least are the works dedicated to pedestrian traffic in cities. These studies are usually based on analyses of the configurational properties of space (Koohsari et al. 2016). These, in turn, usually lead to an assessment of the influence of configuration on the presence of pedestrians and predictions of pedestrian traffic intensity. At this point it can be revealed that, for instance, the correlation between pedestrian movement and the configurational attributes of the built environment is higher than between pedestrian movement and the functional attributes (Lerman \& Omer 2013). It was also confirmed that the spatial structure of urban areas not only plays a major role in the arrangement of pedestrian movement, but also that there are connections between the spatial configuration and land use (Ozbil, Peponis \& Stone 2011). A relationship between the integration of space (streets), the number of people on the streets, and the location of businesses was also confirmed by Penn et al. (1998). Attempts have also been made to connect bicycle and motor movements with the configurational properties of space (Hillier et al. 1993; Raford, Chiaradia \& Gil 2007; Baran, Rodríguez \& Khattak 2008; Jiang 2009 see also Sharmin \& Kamruzzaman 2018).

In conclusion, configurational analysis helps in the search for the relationships between the spatial system and the social processes occurring within it. Therefore, the social functions of the man-made environment are of greatest interest (Hillier \& Hanson 1984; Peponis \& Wineman 2003). Space syntax has become both an inspiration and an analytical tool for other academic 
disciplines and sub-disciplines. These fields conduct studies focusing on the security of society both in a behavioural context (crime, terrorist attacks) and a morphological one (e.g. resistance of urban structures to hazards and disasters).

Hillier (2004) pointed out the existing relationships between crime and spatial design, finding a strong correlation between the type of street layout and various types of crimes. A correlation between space syntax measures and crime in residential estates was also confirmed in research by Shu (2000), among others. On the other hand, Van Nes and López (2010) revealed there is a strong relationship between the spatial arrangement of burglaries and theft from cars, and the spatial configuration of street grids. Other studies have also proven that highly integrated streets (with good accessibility) ensure a lower risk of crimes and antisocial behaviour (Van Nes \& Rueb 2009). These studies indicate that improving the integration of street grids may contribute to an increase in the safety of residential areas. Conformities between the configurational properties of urban space and occurrences of terrorist attacks (Matijosaitiene \& Petriashvili 2017) as well as the spatial patterns of sexual harassment (Mohamed \& Van Nes 2017; Mohamed \& Stanek 2020) are also observable.

However, not all research results are unambiguous. For instance, studies of the relationships between street thefts and burglaries, and the configurational attributes of urban residential areas (Reis, Vedana \& Dittmar 2007) indicated that high integration continues to have a positive correlation with crime rates. This suggests that districts with high accessibility also offer criminals easy access points to crime objectives and escape routes (Hillier \& Sahbaz 2005; Nubani \& Wineman 2005; Lay et al. 2007), and stresses the fact that urban integration and the increase in the level of movement and activity associated with it may reduce crime; yet, at the same time, it may be favourable to criminals who also use those same highly integrated streets, thus making these more available locations more dangerous. Without a doubt both effects occur, and the key variable in determining their scale is the degree to which 'residential culture' exists in those areas with higher activity levels ${ }^{2}$. Space syntax tools make it possible to analyse the morphological properties of spatial layouts, evaluate space, and assess its social functionality and usefulness within existing or designed architectural and urban structures. It is also possible to determine the directions of changes in such a way so as to give space new properties that would produce desired spatial models of social and economic human activity.

As a consequence, these tools support urban, data-informed design and planning that takes into consideration the influence of spatial morphology on the economic value and social qualities of place. Numerous works on fixing and redeveloping urban structures (e.g. as part of revitalisation projects) are examples of data-informed design and planning. They include, for instance, a work dedicated to the harbour area of Rio de Janeiro (Dias \& de Arruda Campos 2015), which indicated that the urban intervention conducted there had limited influence on the general accessibility of the area. Studies in Jeddah, Saudi Arabia on the development of the neighbourhood of its historical core, which was conducted without a plan, focused on the search for precise, and therefore spatially limited, effective interventions in the spatial structure of the city (Karimi et al. 2007). The purpose of an analysis of the configuration of a fragment of Istanbul's urban space was to suggest new communication solutions in order to decrease the level of isolation in some city areas (Önder \& Gigi 2010). Trigueiro \& Medeiros (2007), on the other hand, have discussed the strategy of reclassifying the old centre of Natal in Brazil, and the consequences of interventions planned for this part of the city.

Space syntax research may contribute to a better understanding of the way in which the spatial form of cities

${ }^{2}$ Originally: 'residential culture, culture of civilized co-presence' influences the spatial segregation of their inhabitants. For instance, Vaughan and Penn (2006) conducted studies on the relationship between street layout and the concentration of Jewish immigrants in Manchester and Leeds in the nineteenth century. They proved that there was an inverse correlation between the immigrants' population density and the level of integration of urban space, indicating that immigrants chose areas with lower levels of integration but higher population density. They looked for places favourable to existence and development, but also outof-the-way locations (Vaughan, Clark \& Sahbaz 2005; Legeby 2008).

Other studies, less advanced but with major potential, include works on the functioning of societies at night. Their results showed that people's perception of a given spatial configuration changes under artificial light (Dwimirnani, Karimi \& Palaiologou 2017). Works whose authors focused on the use of space and energy also present interesting perspectives. In reality, most of the works referred to touch upon this issue, though it should be mentioned that space syntax research relates even to such basic problems as the organisation of the construction process (Wu \& Go 2014).

Current space syntax works in Poland. Limits and possibilities for development

Works in the field of space syntax have failed to evoke considerable response in Poland ${ }^{3}$. The number of publications at least mentioning the theory is modest at best ${ }^{4}$. Efforts aimed at utilising space syntax research in practice at the design stage are also few and far between (e.g. the configurational analysis of Warsaw conducted by the architect Joao Pinelo-Silva, graduate of University College London) (Pindor, Skorupka \& Szczepańska 2011). Yet individual, publicised dissertations also indicate that space syntax is present in other research fields, such as, for instance, environmental psychology (Szczepańska 2011).

Among the publications, the biggest group of works comprises those that merely signal or briefly discuss the space syntax current. These include geographical works mostly dedicated to urban morphology (e.g. Szmytkie 2014;Deptuła 2016), spatial planning (Zielińska 2017), transport planning (Książkiewicz 2012), and public space planning (Ratajczak 2018) as well as publications in urban planning, architectural engineering, and architecture. The latter include works dedicated to architecture and urban planning theories (Niezabitowska 2014; Zuziak 2015), and discussions on the perception of place (Lasiewicz-Sych 2016) and its centrality (Awtuch 2008). Works that discuss the theoretical basis and measures of space syntax are much more sporadic. These can be written by geographers (Ratajczak 2013), architects, or urban planners (Zwoliński 2008; Dettlaff 2014; Lasiewicz-Sych 2017).

A separate group includes publications whose authors have conducted research on the basis of the assumptions and methods of space syntax. According to the classification of space syntax works used in this article, these are mostly morphologically-oriented works dedicated to the urban form and methods of its configuration. Works on pedestrian traffic and

Il should also be mentioned that most works containing minor or major references to this field of knowledge have been written by people affiliated with technical units (e.g. with the Faculty of Civil Engineering and Architecture of the Lublin University of Technology, the Faculty of Architecture of the Cracow University of Technology, the Faculty of Architecture of the Silesian University of Technology, the Faculty of Architecture of the Gdańsk University of Technology, and the Faculty of Architecture of the Wrocław University of Science and Technology), and only some have been written by people affiliated with geographical units (e.g. the Faculty of Geographical Sciences of the University of Łódź, the Faculty of Socio-Economic Geography and Spatial Management of the Adam Mickiewicz University, and the Institute of Geography and Spatial Management of the Jagiellonian University).

${ }^{4}$ This is proven by the fact that at the end of 2020 , Google Scholar search engine indexed a mere dozen or so works on space syntax by Polish authors, while Google found less than 50 results actually related to the theory. 
pedestrian accessibility constitute a small percentage, while the issue of land use, in light of the available literature, has not been discussed at all.

Researchers' attention has mostly been drawn to the biggest Polish cities: Wrocław, Łódź, Kraków, and Gdańsk. One of the most comprehensive configurational analyses was conducted for Wrocław (Saeid \& Masztalski 2009). This analysis utilised both global and local syntactic measures of the configurational and structural properties of space based on modern and historical maps of the city. Among other things, the authors presented the spatial layout of areas of local integration and the spatio-temporal transformation of the area with the highest level of integration (the global core of integration of the city). The studies also provided evidence for the ongoing shift of the integration core from the historical centre of Wrockaw to a younger part of the city, with the historical area maintaining its attributes of centrality all the while.

Configurational analyses were also conducted for the central part of Łódź. They made it possible, for instance, to identify nonobvious features of the urban layout, that is, the topological peripheries in its geometrical centre (Lamprecht 2020a). An attempt was made to analyse changes to the configuration of the plan of the contemporary city centre on the basis of historical city plans, indicating, among other things, the historical determinants of the modern, belt-shaped city's core.

A number of analyses for Kraków, at both the large-area scale (Stare Miasto, Nowa Huta, the Kraków Communications Centre) and at the scale of individual premises (Galeria Kazimierz, Bonarka City Center, Galeria Krakowska) were conducted by Nassery and Dudek (2015).

An analysis of the changes to the integration of the Gdańsk street grid, which have been occurring for 200 years (Awtuch 2009), is also worth mentioning. This work made it possible to identify the progressing 'process of disintegration and dispersion of urban structure' caused, according to the author, by 'ill-considered changes to the layout and incidental locations of large service investments'.

It has already been mentioned that analyses mostly concern big city areas. A work dedicated to small towns in the Greater Poland Voivodeship (Lamprecht 2020c) is one of the exceptions. It contains an analysis of changes to the urban layouts of six small towns that differ from each other in terms of changes to the size of their populations. Research showed that both the cities with stable populations and those undergoing depopulation remain unchanging in terms of configuration. On the other hand, cities with growing populations not only expand their urban structures, but also undergo configurational changes of varying degrees (transformations or shifts of their cores).

Works on communication, pedestrian accessibility, and pedestrian traffic in cities are a separate group. The most important works include an analysis and assessment of the central part of Lublin (Kocki \& Kwiatkowski 2016) and the Kośminek district in Lublin (Kocki \& Kwiatkowski 2017). Research dedicated to modelling pedestrian accessibility was also conducted in Gdańsk by assessing the accessibility of public spaces on the campus of the Gdańsk University of Technology (Marczewska 2017). An analysis of the street grid and pedestrian routes in the vicinity of the Kraków-Łobzów railway stop was conducted in Kraków (Książkiewicz 2015), identifying possible corrections to the existing communications system.

Yet, there is still a shortage of works venturing into other academic fields among the Polish publications. One of the exceptions is a work by Awtuch (2006), which identifies the relationships between the configurational features of the Gdańsk residential estates and the sense of safety among their residents.

This continuous lack of a more in-depth discussion on the theoretical models and the results of empirical research that support the theoretical premises, is a result of the marginal significance of space syntax in Polish research. It is likely that the first attempt to assess whether the theoretical models (based on axial lines, natural streets, and new axial lines) match pedestrian movements observed in reality was conducted only recently (Lamprecht 2020b). The research results indicated that all analysed models similarly evaluated the structure of urban space. Generally, the conformity of each model to the observed pedestrian traffic is quite high and statistically significant. In each of the analysed parameters, the model based on natural streets had the highest conformity, yet the divergence of the levels of correlation between the models is small.

In conclusion, the research conducted in Poland is a meagre fraction of international studies. The author's experience dictates that there are several reasons for this. For instance, there is no Polish academic community dedicated to space syntax; the research procedure is highly complex, which means that the software for analyses varies greatly; terminology is unclear ${ }^{5}$; and international connections are insufficient. Therefore, a person interested in space syntax faces the necessity of putting substantial scientific effort into the early stages of research.

Due to the low number of space syntax researchers in Poland, mutual support in a direct academic environment is limited. This increases not only the above-mentioned effort, but also the academic uncertainty regarding, for instance, the research procedures applied or the accuracy of the interpretation. Moreover, the key element of the analyses, which comprises constructing the model of the studied layout and measuring its properties, requires a lot of freedom in the use of diverse software from the CAD and GIS families (e.g. AutoCAD Civil 2020; ArcGIS 2015), as well as those programs or extensions dedicated to such analyses (e.g. DepthmapX 2020; Axwoman 2015), and others not specifically dedicated to space syntax (e.g. Batagelj \& Mrvar 2019). Still, it should be emphasised that the efforts of the academic circles that built the foundation of this current (e.g. Al Sayed et al. 2014; UCL Space syntax 2020; Axwoman Homepage n.d.) greatly facilitate research. Additionally, conducting research that is considered pioneering (in Poland) is, undoubtedly, a source of academic gratification.

Paradoxically, despite the mentioned handicaps, space syntax has a high developmental potential in Poland. This conclusion is drawn from analysing geographers' opinions on the weaknesses and possibilities in Polish geography as well as the threats posed to it (Loboda 2004). The Polish academic environment of geography ${ }^{6}$ feels a strong need to apply and construct new theoretical, valid concepts (e.g. formulating a complex theory of socio-economic space), increase the usefulness of geographical research (with particular focus on spatial planning and predictions, among others), and expand the use of GIS, computer science and other new technologies in research. Therefore, the theory and methodology of space syntax can reinforce some research areas and increase the significance of geographical sciences in Poland. For this purpose, it is crucial for the researchers themselves to undertake actions initiating and supporting the development of space syntax. Developing scientific potential in the form of, for example, research teams, may greatly diminish the enumerated constraints.

\section{Conclusion}

A theory that has been under constant development for several decades and provides the basis for space syntax research is the foundation of space syntax. To this day it has collected

${ }^{5}$ Numerous notions have no Polish equivalents and are translated in various ways, e.g. 'space syntax' alone has three different translations that are used interchangeably.

${ }^{6}$ Surveys conducted among 127 researchers, who were representatives of major Polish geographical centres. 
many achievements in the form of tested, confirmed, and ordered facts regarding the correlations between societies and the spatial configuration of their living environment. Moreover, space syntax is based on analytical techniques and tools that ensure a high level of objectivity. The language used in its descriptions, as well as the spatial measures that constitute the conglomeration of works on urban morphology, mathematics, and network-oriented sciences, are especially valuable. The language, together with the algorithm for building the representation of spatial layouts, helps restrict a researcher's subjectivity and ensures the repetitiveness of the results of analyses. The results obtained are independent of the researchers or, for example, the opinions of the societies that make use of them.

Space syntax tools are useful in the analysis and assessment of spatial structures in terms of the conditions they create for their users. They also make it possible to correct current structures in order to improve the functioning of the societies they were designed for (or, more often, the generations that come after). Space syntax tools also better help plan the spatial configuration of the built environment in order for it to help fulfil the needs of its inhabitants, such as movement or the reproduction of social relations.

Space syntax makes it possible to perceive societal relations anew. This has undoubtedly influenced its popularity among other research disciplines and sub-disciplines. Yet, in Poland this theory is largely marginalised, although the academic environment remains aware of its existence. Moreover, the quoted opinions of geographers suggest that there is a place for space syntax in the Polish academic arena. There is also demand for both its original approach to the rules underlying the functioning of society, and its analytical tools. It appears that there are two factors that influence the current marginalisation of space syntax in Poland. The first one is the relative complexity of the research procedure, which requires knowledge of specialist computer software (at the model preparation and analysis stages). The second arises directly from the only occasional attempts at using the tools of space syntax in reality in the Polish arena. This determines the actual lack of a native space syntax community that would support subsequent researchers that are ready to draw on the works of this discipline. In the author's experience (lecturer in Spatial Development and Planning, at the Faculty of Geographical Sciences, University of Łódź), space syntax enjoys popularity among students and doctoral students, as both a theory and a source of new interpretations of current knowledge. Similar opinions are expressed through the author's personal contacts in the academic community. Therefore, there is a possibility for space syntax development, especially since access to computer software and proficiency in using it is increasing rapidly. Yet, to achieve this, it is crucial for researchers themselves to undertake actions initiating and supporting its development. Developing the scientific potential in the form of, for instance, research teams, may greatly diminish the enumerated constraints.

ORCID

Mariusz Lamprecht (D) https://orcid.org/0000-0002-0418-1115

\section{References}

Abriszewski, K 2008, 'Poznanie, zbiorowość, polityka: analiza teorii aktora-sieci Bruno Latoura' [Knowledge practices, collective, politics. The analysis of Bruno Latour's ActorNetwork Theory], Universitas, Kraków.

Al-Sayed, K, Turner, A, Hillier, B, lida, S \& Penn, A 2014, 'Space syntax methodology', University College of London, London.

Appadurai, A (ed.) 1986, 'The social life of things: commodities in cultural perspective', Cambridge University Press, Cambridge.

AutoCAD Civil 3D, computer software (version 2020) 2020. San Rafael, CA: Autodesk Inc. Available from: <https://www. autodesk.com/education/home>. [20 July 2020].

Awtuch, A 2006, 'Konfiguracja przestrzeni a bezpieczeństwo' [Crime and space configuration], Przestrzeń bezpieczna: urbanistyczne $i$ architektoniczne uwarunkowania kształtowania przestrzeni miejskiej dla zwiększenia bezpieczeństwa mieszkańców [The safe space: urban and architectural conditions of the city space shaping, for the increase of safety of inhabitants], eds. A Wyżykowski \& S Werble-Strzelecka, Wydział Architektury Politechniki Krakowskiej, Kraków.

Awtuch, A 2008, "'Serce nie sługa" - przypadek gdański'[,The heart knows no master" - Gdańsk case] in Czasopismo Techniczne. Architektura, vol. 105(2A), pp. 15-22. Available from: <https://repozytorium.biblos.pk.edu.pl>. [21 July 2019].

Awtuch, A 2009, 'Spatial order and security. Case study of two housing estates' in Proceedings of the 7th International Space Syntax Symposium, eds. D Koch, L Marcus \& J Steen, Stockholm, pp. 5.1.-5.10. Available from: <http:// www.sss7.org>. [21 July 2019].

Aydoğan, H, Şalgamcioğlu, ME 2017, 'Architectural morphology and user behavior relationship in shopping malls' in Proceedings of the 11th International Space Syntax
Symposium, eds. T Heitor, M Serra, JP Silva, M Bacharel \& L Cannas da Silva, Instituto Superior Técnico, Portugal, pp. 1.1-1.19.

Axwoman Homepage (n.d.), Dr. Bin Jiang's main homepage http://giscience.hig.se/binjiang/axwoman/.

Baran, PK, Rodríguez, DA \& Khattak, AJ 2008, 'Space syntax and walking in a new urbanist and suburban neighbourhoods', Journal of Urban Design, vol. 13(1), pp. 5-28.

Barański, J 2007, 'Świat rzeczy: zarys antropologiczny' [The world of things. An anthropological outline], Wydawnictwo Uniwersytetu Jagiellońskiego, Kraków.

Brown, GM 1999, 'Design and value: spatial form and the economic failure of a mall', Journal of Real Estate Research, vol. 17(2), pp. 189-225.

Chiaradia, A, Hillier, B, Barnes, Y \& Schwander, C 2009, 'Residential property value patterns in London' in Proceedings of the 7th International Space Syntax Symposium, eds. D Koch, L Marcus \& J Steen, Stockholm, pp. 15.1-15.12. Available from: <http://www.sss7.org>. [21 July 2019].

Coutinho, BDS, Santos, RF \& Fernandes, A 2017, 'Space syntax as a tool for an open museum practice' in Proceedings of the 11th International Space Syntax Symposium, eds. T Heitor, M Serra, JP Silva, M Bacharel \& L Cannas da Silva, Instituto Superior Técnico, Portugal, pp. 8.1-8.15.

Golledge, RG \& Cox, KR (eds) 1981, 'Behavioral Problems in Geography Revisited', Methuen, London.

Graves, TD 2004, 'Behavioral anthropology: Toward an integrated science of human behavior', Altamira Press, Oxford.

Cox, KR \& Golledge, RG 1986, 'Problemy behawioralne w geografii po dziesięciu latach rozwoju. Geografia behawioralna' [Behavioral problems in geography revisited Preface], Przegląd Zagranicznej Literatury Geograficznej, IGiPZ PAN, vol. 3-4, pp. 9-19. 
DepthmapX, computer software (version 0.8.0) 2010. DepthmapX development team, Space Syntax Laboratory, The Bartlett, UCL. Available from: <https://github.com/SpaceGroupUCL/ depthmapX>

Deptuła, M 2016, 'Tradycyjne szkoły urbomorfologii a nowe podejścia do analizy miejskich form przestrzennych' [Traditional schools of urban morphology and the new approaches to the analysis of urban forms], Acta Universitatis Lodziensis, Folia Geographica Socio-Oeconomica, vol. 25, pp. 25-38.

Dettlaff, W 2014, 'Space syntax analysis - methodology of understanding the space', PhD interdisciplinary Journal, vol. 1, pp. 283-291.

Dias, CR \& de Arruda Campos, MB 2015, 'Urban evolution of the Rio de Janeiro Port' in Proceedings of the 10th International Space Syntax Symposium eds. K Karimi, L Vaughan, K Sailer, G Palaiologou, T Bolton, pp. 57.1-57.12. Available from: <http://www.sss10.bartlett.ucl.ac.uk/>. [18 August 2020].

Dwimirnani, P, Karimi, K \& Palaiologou, G 2017, 'Space after dark: Measuring the impact of public lighting at night on visibility, movement, and spatial configuration in urban parks' in Proceedings of the 11th International Space Syntax Symposium, eds. T Heitor, M Serra, JP Silva, M Bacharel \& L Cannas da Silva, Instituto Superior Técnico, Portugal, pp. 129.1-129.18.

Enström, R \& Netzell, O 2008, 'Can space syntax help us in understanding the intraurban office rent pattern? Accessibility and rents in downtown Stockholm', The Journal of Real Estate Finance and Economics, vol. 36(3), pp. 289305.

ArcGIS Desktop, computer software (version 10.2) 2015. Environmental Systems Research Institute, Redlands, CA.

Foster, S 1989, 'Analysis of spatial patterns in buildings (access analysis) as an insight into social structure: examples from the Scottish Atlantic Iron Age', Antiquity, vol. 63(238), pp. 40-50.

Froy, FE 2016, 'Understanding the spatial organisation of economic activities in early 19th century Antwerp', The Journal of Space Syntax, vol. 6(2), 225-246.

Hall ET, 2001, 'Ukryty wymiar', [The Hidden Dimension], Wydawnictwo Muza, Warszawa.

Haq, S \& Berhie, G 2018,'Space syntax investigation of Lubbock, a grid-like American city and some insights into isotropic layouts', Journal of Urban Design, vol. 23(1), pp. 5-22. Available from: <https://www.tandfonline.com>. [3 November 2020]

Hendrykowski M 2015, 'Proksemika. Studium z antropologii kulturowej' [Proxemics: A study on cultural anthropology], Przestrzenie Teorii, vol. 23, pp. 39-51. Available from: <https://www.ceeol.com>. [3 November 2020]

Hillier, B 2004, 'Can streets be made safe?', Urban Design International, vol. 9(1), pp. 31-45.

Hillier, B 1996, 'Space is the machine: a configurational theory of architecture', Space Syntax, London.

Hillier, B \& Hanson, J 1984, 'The social logic of space', Bartlett School of Architecture and Planning, University College of London, Cambridge.

Hillier, B \& Sahbaz, O 2005, 'High resolution analysis of crime patterns in urban street networks' in Proceedings of the 5th International Space Syntax Symposium, ed. A van Nes, Techne Press, Amsterdam, pp. 451-478. Available from: <http://spacesyntax.tudelft.nl>. [18 August 2019].

Hillier, B 2012, 'The genetic code for cities: is it simpler than we think?', in Complexity Theories of Cities Have Come of Age: An Overview with Implications to Urban Planning and
Design, eds. J Portugali, H Meyer, E Stolk \& E Tan, Springer, London, pp. 67-89.

Hillier, B, Hanson, J \& Graham, H 1987, 'Ideas are in things: an application of the space syntax method to discovering house genotypes', Environment and Planning B: Planning and Design, vol. 14, pp. 363-385.

Hillier, B, Leaman, A, Stansall, P \& Bedford, M 1976, 'Space syntax', Environment and Planning B: Planning and Design, vol. 3(2), pp. 147-185

Hillier, B, Hanson, J, Peponis, J, Hudson, J \& Burdett, R 1983, 'Space syntax. A different urban perspective', Architectural Journal, vol. 30, pp. 47-63.

Hillier, B, Penn, A, Hanson, J, Grajewski, T \& Xu, J 1993, 'Natural movement: or, configuration and attraction in urban pedestrian movement', Environment and Planning $B$ : planning and design, vol. 20(1), pp. 29-66.

Hillier B \& Penn A 2004, 'Rejoinder to Carlo Ratti', Environment and Planning B: Planning and Design, vol. 31(4), pp. 501511.

Jiang, B 2009, 'Ranking spaces for predicting human movement in an urban environment', International Journal of Geographical Information Science, vol. 23(7), pp. 823-837.

Axwoman: An ArcGIS extension for urban morphological analysis, computer software (version 6.3) 2015. Jiang, Bin, Sweden: University of Gävle. Available from: <http://fromto. hig.se/ bjg/axwoman>. [30 June 2017].

Jiang, B, Zhao, S \& Yin, J 2008, 'Self-organized natural roads for predicting traffic flow: a sensitivity study', Journal of Statistical Mechanics: Theory and experiment, vol. 2008, no. 7, pp. 1-27.

Karimi, K 2018, 'Space syntax: consolidation and transformation of an urban research field', Journal of Urban Design, vol. 23(1), pp. 1-4.

Karimi, K, Amir, A, Shafiei, K, Raford, N, Abdul, E, Zhang, J \& Mavridou, M 2007, 'Evidence-Based Spatial Intervention for Regeneration of Informal Settlement: the case of Jeddah central unplanned areas' in Proceedings of the 6th International Space Syntax Symposium, (eds) AS Kubat, Ö Ertekin, YI Güney \& E Eyüboglu, Istanbul Technical University, pp. 034.01-034.14. Available from: <http://www. spacesyntaxistanbul.itu.edu.tr>. [20 January 2020].

Kim, HK \& Sohn, DW 2002, 'An analysis of the relationship between land use density of office buildings and urban street configuration: case studies of two areas in Seoul by space syntax analysis', Cities, vol. 19(6), pp. 409-418.

Kocki, W \& Kwiatkowski, B 2016, 'Space Syntax w strukturze komunikacyjnej Lublina' [Space syntax in communication structure of Lublin], Budownictwo i Architektura, vol. 15(1), pp. 201-211.

Kocki, W \& Kwiatkowski, B 2017, 'Space Syntax w strukturze komunikacyjnej dzielnicy Kośminek w Lublinie' [Space syntax in communication structure of Lublin's district Kośminek], Budownictwo i Architektura, vol. 16(1), pp. 153163.

Koohsari, MJ, Sugiyama, T, Mavoa, S, Villanueva, K, Badland, H, Giles-Corti, B \& Owen, N 2016, 'Street network measures and adults' walking for transport: application of space syntax', Health \& Place, vol. 38, pp. 89-95.

Kostakos, V 2010, 'Space syntax and pervasive systems' in Geospatial Analysis and Modelling of Urban Structure and Dynamics, (eds) B Jiang \& X Yao, pp. 31-52, Springer,

Książkiewicz, S 2012, 'Quantitative or qualitative transport planning? An interdisciplinary geographic perspective', Prace Geograficzne, vol. 130, pp. 131-139.

Książkiewicz, S 2015, 'Modelowanie pieszej dostępności przestrzeni miejskiej w teorii Space Syntax' [Modelling of 
pedestrian accessibility to urban space in the space syntax theory] in Miasto $w$ badaniach geografów, vol. 1, eds. $\mathrm{P}$ Trzepacz, J Więcław-Michniewska, A Brzosko-Sermak \& A Kołoś, IGiGP UJ, Kraków, pp. 183-202.

Lamprecht M 2020a, 'Hidden properties of city plans. A case study of Łódź', European Spatial Research and Policy, vol. 27, no. 2, pp.199-220.

Lamprecht M 2020b, 'Pedestrian movement and Space Syntax measures. Example of the city centre in Łódź, Poland', Studia Miejskie, vol. 37, pp. 23-38.

Lamprecht M 2020c, 'Rozplanowanie małych miast wschodniej Wielkopolski. Analiza zmian w ujęciu konfiguracyjnym' [Urban layout of small towns in eastern Greater Poland. A configurational approach], Rozwój Regionalny i Polityka Regionalna, vol. 52, pp. 59-79.

Lasiewicz-Sych, A 2016, 'Kreacja miejsc a forma otwarta: problem aktywnej percepcji w architekturze' [Placemaking vs an open form: active perception in architecture], Kultura Historia, vol. 30, pp. 90-105.

Lasiewicz-Sych, A 2017, 'Uwagi na temat metod logicznych i jakościowych w diagnozie środowiska architektonicznego' [Notes on the combination of logical argumentation and qualitative methods in diagnosis of the built environment] Architectus, vol. 1(49), pp. 97-114.

Latour, B 2010, 'Splatajac na nowo to, co społeczne: wprowadzenie do teorii aktora-sieci' [Reassembling the social - an introduction to Actor-Network Theory], Universitas, Kraków.

Lay, MCD, Reis, A, Dreux, V \& Becker, D 2007, 'Urban security and spatial behavior: syntactic and perceptual analysis of the central area of Porto Alegre' in Proceeding of the 6th International Space Syntax Symposium, Istambuł, eds. A S Kubat, O Ertekin, Y I Guney \& E Eyuboglu, Istanbul Technical University, Istanbul, pp. 128.1-128.10. Available from: <http://www.spacesyntaxistanbul.itu.edu.tr>. [14

Lefebvre, H 1991, 'The production of space', Blackwell,

Legeby, A 2008, 'What knowledge can a spatial approach add to the understanding of segregation?' Architectural Inquiries, Chalmers University of Technology, Department of Architecture, pp. 1(12)-12(12). Available from: KTH Publication Database DiVA. [15 November 2019].

Lerman, Y \& Omer, I 2013, 'The effects of configurational and functional factors on the spatial distribution of pedestrians', in Geographic Information Science at the Heart of Europe, eds. D Vandenbroucke, B Bucher \& J Crompvoets, Springer Science \& Business Media, Heidelberg, pp. 383-398.

Łoboda, J 2004, 'Stan i perspektywy polskiej geografii w opinii geografów' [Geographers' opinion as to the state of, and prospects for, Polish geography], Przeglad Geograficzny,

Ma, D, Omer, I, Osaragi, T, Sandberg, M \& Jiang, B 2019, 'Why topology matters in predicting human activities', Environment and Planning B: Urban Analytics and City Science, vol. 46(7), pp. 1297-1313.

Marczewska, E 2017, ‘Określenie stopnia dostępności przestrzeni publicznych na kampusie Politechniki Gdańskiej w myśl teorii projektowania uniwersalnego z użyciem metodologii space syntax' [Determining the degree of public space availability on the campus of the Gdansk University of Technology in accordance with the universal design theory using space syntax methodology] in Badania interdyscyplinarne $w$ architekturze [Interdisciplinary Studies in Architecture], vol. 2, ed. B Komar (ed.), pp. 91-103, Wydawnictwo Wydział Architektury Politechniki Śląskiej, Gliwice. Available from: < http://delibra.bg.polsl. pl>. [7 November 2019].
Matijosaitiene, I \& Petriashvili, A 2017, 'Urban planning and design for terrorism resilient cities', Journal of Sustainable Architecture and Civil Engineering, vol. 18(1), pp. 27-38

Ministry of Science and Higher Education 2019, Klasyfikacja dziedzin nauki i dyscyplin naukowych oraz dyscyplin artystycznych [Classification of fields and disciplines of science and disciplines of the arts]. Available from: <https:// konstytucjadlanauki.gov.pl>. [2 November 2020].

Mohamed, AA \& Van Nes, A 2017, 'Street morphology as a starting point for understanding sexual harassment' in Proceedings of the 11th International Space Syntax Symposium, eds. T Heitor, M Serra, JP Silva, M Bacharel \& L Cannas da Silva, Instituto Superior Técnico, Portugal, pp. 197.1-197.8. Available from: < https://repository.tudelft.nl>. [16 August 2019].

Mohamed, AA \& Stanek, D 2020, 'The influence of street network configuration on sexual harassment patterns in Cairo', Cities, vol. 98, 102583. Available from: <https://www.sciencedirect. com>. [30 September 2020].

Montello, DR 2007, 'The contribution of space syntax to a comprehensive theory of environmental psychology' in Proceedings of the 6th International Space Syntax Symposium, (eds) AS Kubat, Ö Ertekin, YI Güney \& E Eyüboglu, Istanbul Technical University, pp. 012.1-012.14. Available from: <http://www.spacesyntaxistanbul.itu.edu.tr>. [8 September 2020].

Nassery, F \& Dudek, M 2015, 'Logistyka przepływu ruchu w konfiguracyjnej teorii space syntax' [Logistics of traffic flow in configuration space syntax theory], Logistyka, vol. 2, pp. 626-638.

Niezabitowska, ED 2014, 'Metody i techniki badawcze w architekturze' [Research methods and techniques in architecture], Wydawnictwo Politechniki Śląskiej, Gliwice.

Netto, MV 2016, "What is space syntax not?" Reflections on space syntax as sociospatial theory', Urban Design International, vol. 21(1), pp. 25-40.

Neuberg, SL, Kenrick, DT, Schaller, M 2010, 'Evolutionary Social Psychology' in: Handbook of social psychology (eds.) ST Fiske, D Gilbert \& G Lindzey, John Wiley \& Sons, New York.

Nubani, L \& Wineman, J 2005, 'The role of space syntax in identifying the relationship between space and crime', in Proceedings of the 5th International Space Syntax Symposium, ed. A van Nes, Techne Press, Amsterdam, pp. 413-422. Available from: <http://spacesyntax.tudelft.nl>. [18 August 2019]

Olsen, B 2013, 'W obronie rzeczy. Archeologia i ontologia przedmiotów' [In defense of things. Archaeology and the ontology of objects (archaeology in society)], Nowa Humanistyka, Warszawa.

Omer, I \& Goldblatt, R 2016, 'Spatial patterns of retail activity and street network structure in new and traditional Israeli cities', Urban Geography, vol. 37(4), pp. 629-649.

Ozbil, A, Peponis, J \& Stone, B 2011, 'Understanding the link between street connectivity, land use and pedestrian flows', Urban Design International, vol. 16(2), pp. 125-141.

Önder, DE \& Gigi, Y 2010, 'Reading urban spaces by the spacesyntax method. A proposal for the South Haliç Region', Cities, vol. 27, pp. 260-271.

Pafka, E., Dovey, K \& Aschwanden, G 2018, 'Limits of space syntax for urban design: Axiality, scale and sinuosity', Environment and Planning B: Urban Analytics and City Science, vol. 47(3), pp. 508-522.

Pajek - Program for Large Network Analysis, computer software (version 5.08) 2019. Batagelj, V \& Mrvar A. Available from <http://mrvar.fdv.uni-lj.si/pajek>. [18 December 2019]. 
Penn, A, Hillier, B, Bannister, D \& Xu, J 1998, 'Configurational modelling of urban movement networks', Environment and Planning (B): Planning and Design, vol. 25(1), pp. 59-84.

Peponis, J \& Wineman, J 2003, 'Spatial structure of environment and behavior' in Handbook of environmental psychology, eds. RB Bechtel \& A Churchman, John Wiley \& Sons, New York, pp. 271-291.

Pindor, P, Skorupka, A, Szczepańska J 2011, 'Psychologia i składnia przestrzeni' [Psychology and space syntax]. Available from: <http://sztuka-architektury.pl/article/4546/ psychologia-i-skladnia-przestrzeni>. [14 July 2019].

Porta, S, Latora, V, Wang, F, Rueda, S, Strano, E, Scellato, S, Cardillo, A, Belli, E, Càrdenas, F, Cormenzana, B \& Latora, L 2012, 'Street centrality and the location of economic activities in Barcelona', Urban Studies, vol. 49(7), pp. 14711488.

Raford, N, Chiaradia, A \& Gil, J 2007, 'Space syntax: the role of urban form in cyclist route choice in central London', UC Berkeley Research Reports, University of California, pp. 1-18. Available from: <https://safetrec.berkeley.edu>. [21 November 2019]

Ramzy, NS 2016, 'Morphological logic in historical settlements: Space syntax analyses of residential districts at MohenjoDaro, Kahun and Ur', Urban Design International, vol. 21(1), pp. 41-54

Ratajczak, W 2013, 'Obiekty, struktury i procesy przestrzenne. Analiza fraktalna' [Spatial objects, structures and processes. A fractal analysis], Bogucki Wydawnictwo Naukowe, Poznań.

Ratajczak, W 2018, 'Przestrzeń publiczna w aspekcie geograficznym i społecznym' [Public space in geographical and social aspects], in Teoretyczne $i$ aplikacyjne wyzwania współczesnej geografii społeczno-ekonomicznej [Theoretical and application challenges of contemporary socio-economic geography], ed. P Churski, Studia KPZK, vol. 183, Warszawa, pp. 103-117.

Ratti, C 2004, 'Space syntax: some inconsistencies', Environment and Planning B: Planning and Design, vol. 31(4), pp. 487499.

Ratti, C 2005, 'Suggestions for developments in space syntax' in Proceedings of the 5th International Space Syntax Symposium, ed. A van Nes, Techne Press, Amsterdam, pp. 13-17. Available from: < http://spacesyntax.tudelft.nl>. [18 August 2019].

Reis, AT, Vedana, L \& Dittmar, C 2007, 'An analysis of street robbery and residential burglary through integration of axial lines, segments connectivity and GIS', in Proceeding of the 6th International Space Syntax Symposium, Istambuł, eds. A S Kubat, O Ertekin, Y I Guney \& E Eyuboglu, Istanbul Technical University, Istanbul pp. 025.1-025.12. Available from: <http://www.spacesyntaxistanbul.itu.edu.tr>. [16 August 2019]

Saeid, AAH \& Masztalski, R 2009, 'Spatial analysis of urban network of Wrocław', Europa XXI, vol. 12, pp. 71-89.

Schleretch, T 1991, 'Material culture or material life. Discipline or field? Theory or method?' in Living in material world. Canadian and American Approaches to Material Culture, ed. GL Pocius, Social and Economic Papers, vol. 19, pp. 231-252.

Serra, M \& Pinho, P 2013, 'Tackling the structure of very large spatial systems. Space syntax and the analysis of metropolitan form', The Journal of Space Syntax, vol. 4(2), pp. 179-196.

Sharmin, S \& Kamruzzaman, M 2018, 'Meta-analysis of the relationships between space syntax measures and pedestrian movement', Transport Reviews, vol. 38(4), pp. 524-550.
Shu, CF 2000, 'Housing layout and crime vulnerability', Urban Design International, vol. 5, no. 3-4, pp. 177-188.

Soja, E 2009, 'The city and spatial justice', International conference Spatial Justice, Nanterre, Paris, March 12-14, 2008, transl. Sophie Didier, Frédéric Dufaux. Available from: <http://www.jssj.org>. [26 July 2019].

Place Syntax Tool, computer software (version 3.1.4) 2020. Ståhle, A, Marcus, L, Koch, D, Fitger, M, Legeby, A, Stavroulaki, G, Pont, MB, Karlström, A, Carranza, PM, Nordström, KTH School of Architecture, Chalmers School of Architecture (SMoG) and Spacescape AB.

Szczepańska, J 2011, 'Demokracja przez projekt? -wykorzystanie teorii space syntax do zrozumienia współobecności różnych użytkowników w przestrzeni publicznej' [Democratic by design? Applying Space Syntax to studying spatial coexistence of diverse users], MA thesis in the field of Environmental Psychology under the supervision of prof. UW, dr hab. Maria Lewicka. Available from: <https://www. academia.edu>. [10 November 2020].

Szmytkie, R 2014, 'Metody analizy morfologii i fizjonomii jednostek osadniczych' [Methods for analysing the morphology and physiognomy of settlement units], Instytut Geografii i Rozwoju Regionalnego Uniwersytetu Wrocławskiego, Wrocław.

Tomko, M, Winter, S \& Claramunt, C 2008, 'Experiential hierarchies of streets', Computers, Environment and Urban Systems, vol. 32(1), pp. 41-52

Trigueiro, EBF\& Medeiros, V 2007, 'The bridge, the market, a centrality forever lost and some hope' in Proceedings of the 6th International Space Syntax Symposium, (eds) AS Kubat, Ö Ertekin, YI Güney \& E Eyüboglu, Istanbul Technical University, pp. 036.01-036.12. Available from: <http://www. spacesyntaxistanbul.itu.edu.tr>. [20 March 2020].

Turner, A 2001, 'Angular analysis' in Space Syntax: 3rd International Symposium, eds. J Peponis, D Wineman, S Bafna, University of Michigan, Atlanta, pp. 1-13. Available from: <http://www.academia.edu>. [25 August 2019].

Turner, A 2005, 'Could a road-centre line be an axial line in disguise' in Proceedings of the 5th International Space Syntax Symposium, ed. A van Nes, Techne Press, Amsterdam, pp. 145-159. Available from: <http://spacesyntax.tudelft.nl>. [18 August 2019].

Turner, A, Penn A \& Hillier B 2005, 'An algorithmic definition of the axial map', Environment and Planning B: Planning and Design, vol. 32(3), pp. 425-444.

UCL Space syntax 2020. Online Training Platform Available from: <http://otp.spacesyntax.net>. [25 August 2019].

Van Nes, A 2009, 'Measuring the degree of street vitality in excavated towns: how can macro and micro spatial analyses tools contribute to understandings on the spatial organization of urban life in Pompeii?' in Proceedings of the 7th International Space Syntax Symposium, eds. D Koch, L Marcus \& J Steen, Stockholm, pp. 120.1-120.11. Available from: <http://www.sss7.org>. [21 July 2019].

Van Nes, A \& López, M 2010, 'Macro and micro scale spatial variables and the distribution of residential burglaries and theft from cars: an investigation of space and crime in the Dutch cities of Alkmaar and Gouda', The Journal of Space Syntax, vol. 1(2), pp. 296-314.

Van Nes, A \& Rueb, L 2009, 'Spatial behaviour in Dutch dwelling areas: how housing layouts affects the behaviour of its users' in Proceedings of the 7th International Space Syntax Symposium, eds. D Koch, L Marcus \& J Steen, Stockholm, pp. 123.-123.16. Available from: <http://www.sss7.org>. [21 July 2019].

Van Nes, A \& Yamu, C 2020, 'Exploring Challenges in Space Syntax Theory Building: The Use of Positivist and 
Hermeneutic Explanatory Models', Sustainability, vol. 12(17), 7133.

Van Nes, A \& Yamu, C 2018, 'Space Syntax: A method to measure urban space related to social, economic and cognitive factors' in The Virtual and the Real in Planning and Urban Design: Perspectives, Practices and Applications, (eds) C Yamu, A Poplin, O Devisch, G de Roo, pp. 136-150, Routledge: Oxon, UK / New York, USA.

Vaughan, L \& Penn, A 2006, 'Jewish immigrant settlement patterns in Manchester and Leeds 1881', Urban Studies, vol. 43(3), pp. 653-671.

Vaughan, L, Clark, DLC \& Sahbaz, O 2005, 'Space and exclusion: the relationship between physical segregation, economic marginalisation and poverty in the city', in Proceedings of the 5th International Space Syntax Symposium, ed. A van Nes, Techne Press, Amsterdam, pp. 379-394. Available from: <http://spacesyntax.tudelft.nl>. [18 August 2019].

Wilson, EO 1975, 'Sociobiology. The new synthesis', Cambridge

Wu, LW \& Guo, SJ 2014, 'An application of space syntax to critical working space analysis: the case of building construction', Journal of Marine Science and Technology, vol. 22(5), pp. 572-582.

Zeisel, J 1975, Sociology and architectural design, Russell Sage Foundation, New York.

Zielińska, S 2017, 'Przestrzeń i jej składnia a zagospodarowanie przestrzenne' [Space syntax and built environment] in Teoretyczne $i$ praktyczne aspekty prawa gospodarki przestrzennej [The theoretical and practical aspects of the spatial economy law], (eds) W Ratajczak, M Szewczyk, J Weltrowska, Bogucki Wydawnictwo Naukowe, Poznań, pp. 153-160

Zuziak, Z 2015, 'Idea miasta i teorie planowania' [The idea of the city and planning theories], Czasopismo Techniczne. Architektura, vol. 12A, pp. 9-27.

Zwoliński, A 2008, 'Wyznaczniki urbanistycznej transformacj zespołów mieszkaniowych w oparciu o parametry użytkowania przestrzeni publicznych' [Determinants of urban transformation of housing areas on the basis of spatial parameters of public spaces], Przestrzeń i forma, no. 10, pp. 289-304. 